\title{
ON SOME NEW PHLEOTHRIPID尼 (THYSANOPTERA) FROM THE TRANSVAAL
}

\author{
By J. Douglas Hood, \\ University of Rochester.
}

The new species described below constitute only a very small part of a collection of Thysanoptera made in the Transvaal by Mr. Jacobus C. Faure, Professor of Entomology in the Transvaal University College, at Pretoria. The descriptions were prepared early in 1924, before I learned that Mr. Faure had himself decided to work up the Thysanoptera of Southern Africa, and while I was engaged in special studies of the genera to which they belong. It is to be hoped that Mr. Faure will soon publish his interesting observations on the group.

\section{Compsothrips recticeps sp. nov.}

Female (apterous).-Length about $2.9 \mathrm{~mm}$. Color nearly black, with posterior margin of pterothorax, first abdominal segment, sides of second segment, and a pair of lateral blotches on fifth segment, white; trochanters, and hind coxæ, brown; antennæ nearly black, excepting apical portion of segment 2, which is brownish yellow, and segment 3, which is brownish yellow and heavily shaded with blackish brown near base and at apex; subhypodermal pigmentation purple.

Head 2.3 times as long as wide, broadest across eyes, surface nearly smooth, lightly reticulate at base; cheeks nearly parallel in anterior three-fifths, slightly converging posteriorly; anterior prolongation of head with sides slightly converging anteriorly; vertex flattened, sloping downward, and with a slight median ridge in lower portions; frontal costa slightly concave; three pairs of short, knobbed bristles on head, the anterior pair longest and situated near anterior angles of eyes, the middle pair just in front of posterior margins of eyes, the posterior pair well down on cheeks and somewhat more than twice their length behind eyes. Eyes protruding, less than one-fourth as long as head and less than one-half as wide as their interval. Ocelli wanting. An- 
tennæ about one and one-third times as long as head; segment 3 about equal to 1 and 2 together and 1.4 times the length of 4; 4-7 prolonged ventrally ${ }^{1}$ at apex, 4 and 7 only slightly; all bristles and sense cones particularly short and weak. Mouth cone shorter than its width at base, about reaching middle of prosternum, broadly rounded at apex, tip of labrum not attaining that of labium.

Prothorax less than one-half as long as head and (inclusive of coxæ) about 1.6 times as wide as long, surface nearly smooth, with sides and the abruptly declivous posterior margin lightly subreticulate; midlaterals minute, all other bristles present, brownish yellow, knobbed and about equal to postoculars and coxals. Pterothorax very small, decidedly narrower than prothorax; mesoscutum transversely striate with anastomozing lines, becoming subreticulate at sides; metascutum subreticulate at sides and base, rather closely longitudinally striate elsewhere. Wings wanting. Legs long and slender, with femora and tibiæ (particularly those of posterior legs) arcuate; fore tarsi armed with a long, stout tooth.

Abdomen broad and heavy, fully 1.5 times as wide as prothorax. Tube less than half as long as head and about twice as long as basal width, which is twice the apical. Bristles nearly colorless, long, nearly pointed; terminal bristles brownish, about 0.7 as long as tube.

Measurements of holotype ( o ): Length $2.90 \mathrm{~mm}$; head, length $0.593 \mathrm{~mm}$., width (across eyes) $0.257 \mathrm{~mm}$., width at base $0.204 \mathrm{~mm}$.; eyes, length $0.128 \mathrm{~mm}$., width $0.060 \mathrm{~mm}$., interval $0.135 \mathrm{~mm}$; prothorax, length $0.255 \mathrm{~mm}$., width (inclusive of coxæ) $0.408 \mathrm{~mm}$; pterothorax, width $0.330 \mathrm{~mm}$.; abdomen, width $0.638 \mathrm{~mm}$; tube, length $0.249 \mathrm{~mm}$., width at base $0.126 \mathrm{~mm}$., at apex $0.061 \mathrm{~mm}$.

$\begin{array}{lrrrrrrrr}\text { Antennal segments: } & 1 & 2 & 3 & 4 & 5 & 6 & 7 & 8 \\ \text { Length }(\mu) & 84 & 90 & 170 & 119 & 115 & 102 & 63 & 60 \\ \text { Width }(\mu) & 57 & 43 & 44 & 45 & 41 & 38 & 31 & 20 \\ \text { Total length of antenna } & 0.80 \mathrm{~mm} . & & & & \end{array}$

1Several genera of Phlœothripidæ have certain of the intermediate antennal segments prolonged in this way, and the teeth so formed are set with a series of short, sensory bristles. Various entomologists have described these teeth as being situated on the dorsal surface of the antennæ, whereas they are clearly ventral in position. 
Described from 2 females taken by Mr. J. C. Faure at Duivelskloof, Transvaal, December 7, 1918, "on grass" (No. 407).

The coloration of the antennæ and body associate this species with $C$. albosignatus (Reuter) from which it differs most conspicuously in the much shorter third antennal segment and the shape of the head.

\section{Stictothrips gen. nov.}

\section{(Stiktos, spotted; thrips a wood worm)}

Depressed; roughened, non-shining and mottled above; glabrous beneath. Head not elongate, rounded but not swollen behind eyes, narrowed at base; cheeks with several prominent funnel-shaped bristles; vertex with a cup-like depression or groove, with the anterior ocellus at its upper edge. Eyes large, rounded and closely facetted, dorsal extent much greater than ventral. Fore femora not enlarged nor toothed; fore tarsi armed in both sexes. Wings of fore pair broad at base, abruptly constricted at basal two-fifths, apical three-fifths narrow, parallelsided, delicately but distinctly reticulate, without median vein. Abdomen with a broad dorsal furrow for the reception of the wings. All prominent body bristles fan-shaped. Terminal bristles shorter than tube, pointed.

Genotype: Phloothrips maculatus Hood.

Closest to Neurothrips, even to the general plan of coloration and the habits of the two known species, but separable by the absence of the median vein of the wing, the less swollen cheeks, and the short terminal bristles.

\section{Stictothrips faurei sp. nov.}

Female (macropterous).-Length about $1.6 \mathrm{~mm}$. Color (to naked eye or as seen under hand lens) pale yellowish brown, intricately mottled with white and brown, with head, pterothorax, and tube dark brown, and appendages annulate with blackish brown. Under $16 \mathrm{~mm}$. objective, the color appears paler-more nearly brownish yellow; head pale brown, vertex yellow, a narrow, median brown streak on dorsum of head behind eyes, 
and a small, white, lateral spot at extreme base, cheeks narrowly edged with brown; antennæ straw-yellow, with segments 4, 6 and 8 dark blackish brown, except pedicel and apex of 4 and pedicel of 6 , which are yellow, and outer surface of 1 , inner and outer surfaces of 2 , pedicel of 3 , and sides and apical portion of 7 , which are shaded with brown; prothorax pale straw-yellow, anterior plate at hind angles brown, posterior plate white, coxæ and ventral plates brown; pterothorax with sides brown and darkest posteriorly, dorsum paler, brownish yellow; mesoscutum with anterior angle white and a dark brown blotch on posterior margin at middle; metascutum with a pair of tooth-like dark brown blotches directed posteriorly, their points paler, and nearly or quite touching; legs pale yellowish, with tarsi nearly black, tibiæ broadly ringed with dark brown just before middle, and femora with a dark brown blotch on inner, and one on outer, surface; wings colorless or lightly clouded with yellowish; segment 1 of abdomen yellowish, with a median, pale brown blotch, and with the pair of small plates at base dark brown; remaining segments (excepting 8-10) with a pale brown blotch at middle, with a white one on either side, followed by a dark brown one (much the largest on segment 2), and at extreme lateral margins, by a small pale brown one, the area in front of the latter white, all blotches becoming less distinct on the more posterior segments; segment 8 with two pairs of small brown spots, arranged in a transverse row, the outer pair involving the stigmata; 9 with two pairs of small brown spots, arranged in two longitudinal rows; tube dark blackish brown apically and at sides of base, remainder pale yellow.

Head about 1.1 times as long as wide, broadest behind eyes, converging to base, the latter about 0.8 the greatest width, dorsal and ventral surfaces lightly reticulate (not clearly visible in all specimens), cheeks minutely serrate and set with about five pairs of transparent, trumpet-shaped bristles; vertex with a cup-shaped depression, the anterior ocellus located on upper margin of cup and directed forward; sides of head in front of eyes produced anteriorly to form a pair of strong teeth slightly overhanging outer margin of first antennal segment. Eyes large and rounded, very closely facetted, prolonged posteriorly on 
dorsal surface of the head.' Ocelli exactly equidistant, pigment red. Antennæ almost exactly as figured in the original description of the genotype, but more slender (see measurements) and without infundibuliform bristles at base of segment 2 and apex of segment 3 ; sense cones as in figure of that species. Mouth cone acute, about attaining posterior margin of prosternum, labrum acutely pointed.

Prothorax somewhat more than half as long as head and (inclusive of coxæ) nearly 2.4 times as wide as long, surface finely granulate; all usual bristles present, broadly dilated, fan-like, so transparent as to be easily overlooked; posterior plate at hind angles with two bristles, instead of one, the posterior bristle the largest on prothorax. Pterothorax wider than prothorax, sides subparallel for half their length, then roundly converging to base of abdomen. Wings of fore pair sharply constricted near middle, where there is a short median thickening; basal portion without fringe on anterior margin, but with about 8 minute hairs in outer portion of posterior margin; distal portion of wing rather sparsely fringed, without accessory hairs; entire wing roughened and lightly but distinctly reticulate; subbasal bristles set close to base of wing, minute, expanded. Legs short, fore and hind femora swollen, fore tarsi with a long, slender, hooked tooth; leg bristles mostly expanded apically.

Abdomen distinctly broader than prothorax. Tube nearly two-thirds as long as head, unusually slender, more than three times as long as basal width which is hardly twice the apical, slightly widened at base, sides slightly converging apically. Bristles broad, nearly clavate, almost transparent, the lateroventral pair on segment 9 longer and pointed; terminal bristles yellowish, hardly twice as long as tube.

Measurements of holotype ( 9 ): Length $1.55 \mathrm{~mm}$; head, length $0.252 \mathrm{~mm}$., width $0.221 \mathrm{~mm}$, width at base $0.182 \mathrm{~mm}$;

${ }^{1}$ In the original description of $S$. maculatus (Hood), Entomological News, XX, 1909 , p. 250 , the eyes are said to be reniform, and are so shown in the figure given on page 251. As the wings of the unique type had not been spread, and as the coloration was so dark as to make difficult any detailed study of the chitinous exoskeleton, the writer ventured to clear the specimen in potassium hydroxide and remount it; and subsequent study shows the eyes to be broadly rounded posteriorly, and not at all reniform. Only the type is known. 
eyes, length $0.111 \mathrm{~mm}$., width $0.065 \mathrm{~mm}$., interval $0.084 \mathrm{~mm}$; prothorax, length $0.135 \mathrm{~mm}$., width (inclusive of coxæ) 0.323 mm.; pterothorax, width $0.350 \mathrm{~mm}$.; abdomen, width 0.540 $\mathrm{mm}$.; tube, length $0.161 \mathrm{~mm}$., width at base $0.050 \mathrm{~mm}$., at apex $0.029 \mathrm{~mm}$.

$\begin{array}{lrrrrrrrr}\text { Antennal segments: } & 1 & 2 & 3 & 4 & 5 & 6 & 7 & 8 \\ \text { Length }(\mu) & 48 & 69 & 78 & 61 & 57 & 51 & 44 & 39 \\ \text { Width }(\mu) & 30 & 32 & 28 & 31 & 28 & 26 & 21 & 11\end{array}$

Total length of antenna $0.45 \mathrm{~mm}$.

Male (macropterous).-Apparently similar to female in all respects, excepting for the smaller size and slenderer form.

Described from 11 females and 7 males taken by Mr. J. C. Faure at Malelane, Transvaal, December 12, 1918, "on pawpaw tree trunk" (No. 403).

A particularly beautiful species, quite distinct from its North American congener, and one which I take pleasure in naming after its discoverer.

\section{Plectrothrips atactus sp. nov.}

Female (brachypterous).-Length about $1.8 \mathrm{~mm}$. Color pale brownish yellow, shaded with blackish brown on front margin of head, cheeks, posterior margin of prothorax, mesothorax (particularly at sides) and second abdominal segment; tube with a reddish cast; legs and antennæ yellow; no subhypodermal pigmentation except the three, bright-red, ocellar spots.

Head smooth above, roughened at sides, 1.2 times as long as wide, broadest midway between eyes and base of head, cheeks rounded; postocular bristles pointed, much shorter than eyes, almost lateral in position; other cephalic bristles minute. Eyes moderately small, hardly one-third as long as head and about 0.4 as wide as their interval. Ocelli situated far forward, the anterior one almost between bases of antennæ, the posterior pair very widely separated, situated close to anterior angles of eyes. Antennæ of structure normal to the genus ${ }^{1}$, except that

${ }^{1}$ See Hood, Ins. Insc. Menstr., Vol. IV, 1916, Pl. 1, fig. 4. 
segment 8 is more slender than usual and distinctly the longest in entire antenna, and segment 6 has no long sense cone on the outer surface at apex. Mouth cone shorter than wide, broadly rounded at apex.

Prothorax smooth, about equal in length to head and (inclusive of coxæ) about twice as wide as long, notum not attaining lateral margins, median thickening distinct; one pair of pointed bristles at posterior angles, somewhat longer than postoculars and subequal to coxals; other bristles minute. Pterothorax about as wide as prothorax. Wings short and scalc-like. Legs short and stout; fore tibiæ not toothed on inner surface of apex; middle and hind tibix with the usual long stout spines; fore tarsus with a long; curved tooth.

Abdomen of normal structure; tube 0.7 as long as head and about twice as wide at base as at apex, sides slightly concave, apex slightly constricted. Bristles long and pointed; terminal bristles much shorter than tube.

Measurements of holotype (o ): Length $1.83 \mathrm{~mm}$; head, length $0.230 \mathrm{~mm}$., width $0.191 \mathrm{~mm}$.; eyes, length $0.070 \mathrm{~mm}$., width $0.039 \mathrm{~mm}$., interval $0.096 \mathrm{~mm}$; postocular bristles, length $0.057 \mathrm{~mm}$.; prothorax, length $0.198 \mathrm{~mm}$., width (inclusive of coxæ) $0.390 \mathrm{~mm}$.; pterothorax, width $0.390 \mathrm{~mm}$.; abdomen, greatest width $0.456 \mathrm{~mm}$; tube, length $0.165 \mathrm{~mm}$., width at base $0.086 \mathrm{~mm}$., at apex $0.046 \mathrm{~mm}$.

$\begin{array}{lrrrrrrrr}\text { Antennal segments: } & 1 & 2 & 3 & 4 & 5 & 6 & 7 & 8 \\ \text { Length }(\mu) & 49 & 63 & 58 & 60 & 56 & 55 & 55 & 67 \\ \text { Width }(\mu) & 44 & 43 & 43 & 44 & 36 & 31 & 24 & 14 \\ \text { Total length of antenna } 0.46 \mathrm{~mm} . & & & & \end{array}$

Male (brachypterous).- Similar to female except for the somewhat smaller size, slenderer abdomen, and the more enlarged prothorax and fore legs. Ninth abdominal tergite slightly prolonged at middle of posterior margin to form a thin, semicircular plate overlying the tube.

Described from 20 females and 5 males taken by Mr. J. C. Faure at Boksburg, Transvaal, April 21, 1914, "under dead Eucalyptus bark" (No. 401).

The long terminal segment of the antenna and the absence of the usual sense cone from the outer surface of the sixth antennal 
segment should serve to distinguish this species. The structure of the 9 th abdominal tergite of the male is interesting. The same process occurs in $P$. antennatus Hood but is lacking in $P$. pallipes Hood.

\section{Trichothrips transvaalensis sp. nov.}

Female, forma brachyptera.-Length about $1.7 \mathrm{~mm}$. Color brown, with pterothorax somewhat lighter and head yellow; femora concolorous with body, except fore pair, which are yellow apically; tibiæ paler than femora, mid and hind pairs shaded with brown; tarsi yellow; tube brown, paler at extreme base and in apical half; antennæ dark blackish brown, excepting segments 1, 2 and 3, which are pale brown, with base of 1, apex of 2 and pedicel of 3 pale yellow; subhypodermal pigmentation red.

Head slightly longer than broad, widest at middle of cheeks, abruptly rounded to eyes and slightly converging to base of head; occipital region faintly subreticulate and with the usual bristles on cheeks rather stout and prominent; postocular bristles less than half as long as head, pointed. Eyes small, directed forward, less than one-fourth the length of the head, and about five-eights as wide as their interval. Ocelli usually wanting, but sometimes minute and barely visible, in which case the anterior one is situated well down toward antennæ, and the posterior ones opposite middle of eyes. Antennæ distinctly more than twice the length of the head; segment 1 tapering to apex; 2 much longer and narrower than 1; 3 the longest, subconical; 4-8 successively shorter and narrower; 8 lanceolate, pedicellate, pedicel somewhat dilated at base; sense cones: $3,1-2 ; 4,2-2$; $5,1-1+1 ; 6,1-1+1 ; 7$ with one on dorsum near apex. Mouth cone reaching nearly across prosternum, semicircularly rounded at apex, tip of labrum about attaining that of labium.

Prothorax nearly 0.9 as long as head and (inclusive of coxæ) about twice as wide as long; anterior marginal and anterior angular bristles about half as long ais postoculars; others long, pointed, midlaterals and inner pair at posterior angles about as long as postoculars, the other pair shorter but longer than coxals. 
Pterothorax about as wide as prothorax, sides almost parallel. Wings minute. Fore tarsus with a moderately long, stout tooth.

Abdomen broad, 1.4 times as wide as prothorax. 'Tube about 0.8 as long as head, about twice as long as basal width, and distinctly more than twice as broad at base as at apex. Bristles long and pointed, those on the ninth segment somewhat shorter, subequal to terminal bristles, two-thirds as long as tube.

Measurements of holotype (o): Length about $1.74 \mathrm{~mm}$.; head, length $0.228 \mathrm{~mm}$., greatest width $0.209 \mathrm{~mm}$., width at base $0.188 \mathrm{~mm}$; eyos, length $0.052 \mathrm{~mm}$., width $0.048 \mathrm{~mm}$., interval $0.081 \mathrm{~mm}$.; postocular bristles, length $0.090 \mathrm{~mm}$; prothorax, length $0.200 \mathrm{~mm}$., width (inclusive of coxæ) 0.408 mm.; pterothorax, width $0.413 \mathrm{~mm}$; abdomen, width 0.573 mm.; tube, length $0.180 \mathrm{~mm}$., width at base $0.091 \mathrm{~mm}$., at apex $0.043 \mathrm{~mm}$.

$\begin{array}{lrrrrrrrr}\text { Antennal segments: } & 1 & 2 & 3 & 4 & 5 & 6 & 7 & 8 \\ \text { Length }(\mu) & 54 & 67 & 78 & 71 & 66 & 62 & 51 & 48 \\ \text { Width }(\mu) & 45 & 32 & 35 & 34 & 31 & 30 & 26 & 18 \\ \text { Total length of antenna } & 0.50 \mathrm{~mm} . & & & & \end{array}$

Female, forma macroptera.--Head concolorous with body, instead of yellow; eyes much larger, rounded, their width nearly equal to their interval; ocelli large, the anterior one situated in front of eyes and overhanging; pterothorax broader than prothorax; wings broad, colorless, fore pair with 8 or 9 accessory hairs on posterior margin; outer subbasal bristle on fore wings short and pointed, others three times as long and capitate.

Male (brachypterous).-Only slightly smaller than female and quite similar in general structure; fore femora greatly swollen, tarsal tooth much stronger, nearly triangular.

Described from 30 females and 20 males, taken by Mr. J. C. Faure at Johannesburg, Transvaal, April 21, 1914, under dead Eucalyptus bark (No. 404).

A true Trichothrips, with the terminal antennal segment pedicellate. Separable from its congeners by the coloration, the rather long third antennal segment, and the details of chætotaxy. 

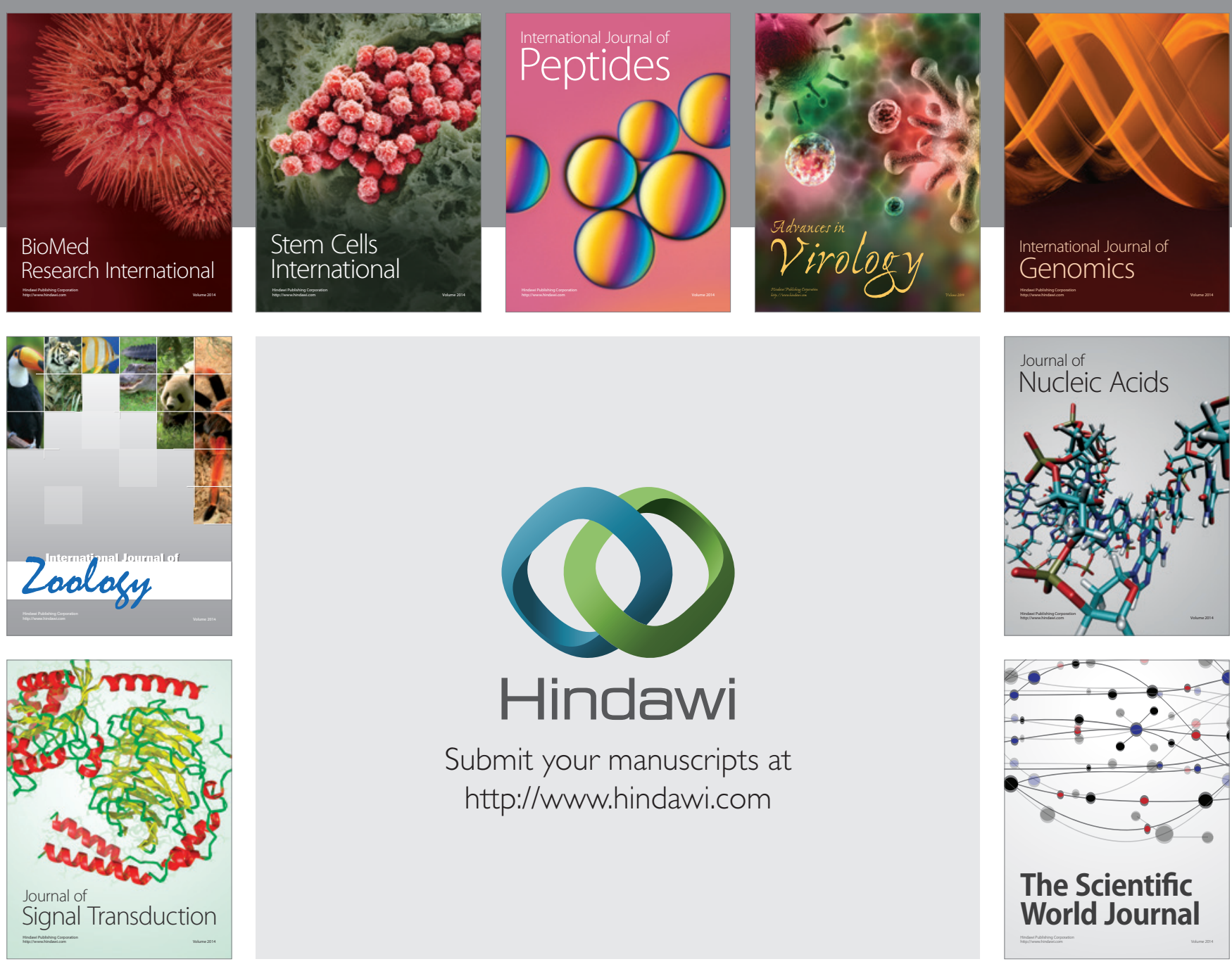

Submit your manuscripts at

http://www.hindawi.com
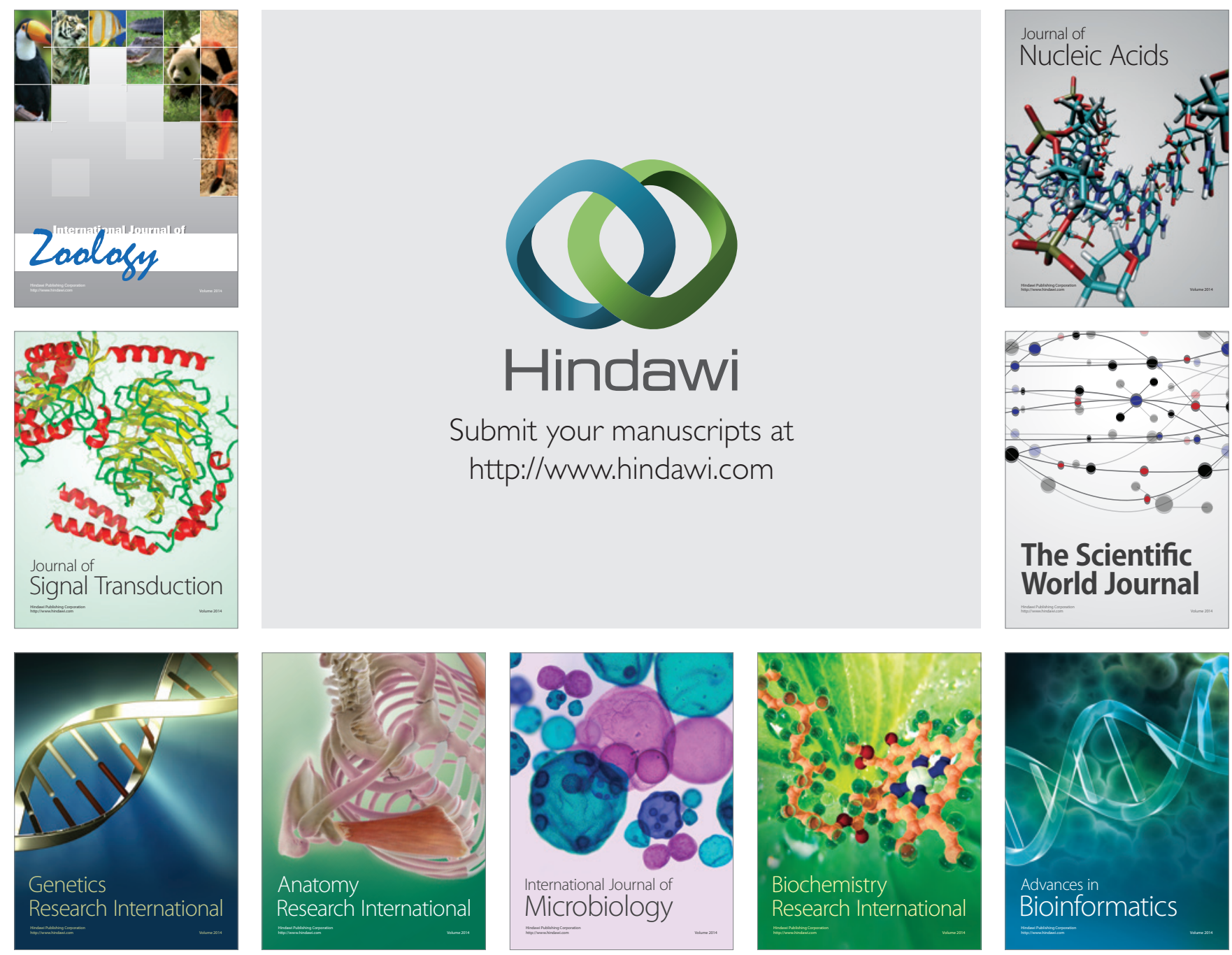

The Scientific World Journal
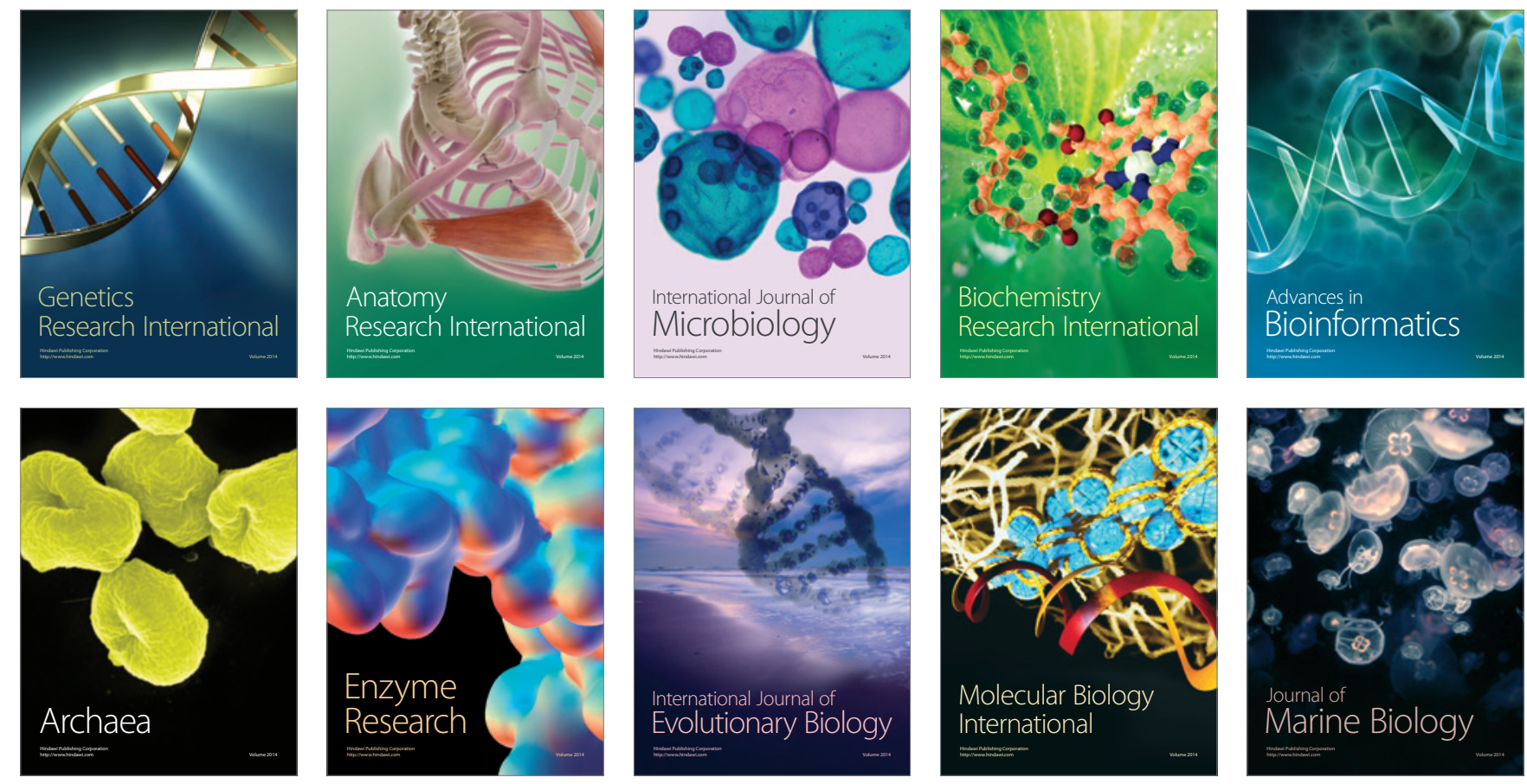